\title{
Analysis of chemical composition and its analgesic and anti- inflammatory activity of essential oil of sintoc bark (Cinnamomum sintoc bl.) using in vivo methods
}

\author{
Sri Adi Sumiwi, Anas Subarnas, Supriyatna Supriyatna, Marline Abdasah, Muchtaridi Muchtaridi* \\ Faculty of Pharmacy Universitas Padjadjaran, Bandung, Indonesia.
}

\begin{tabular}{l} 
ARTICLE INFO \\
\hline Article history: \\
Received on: $28 / 12 / 2014$ \\
Revised on: $18 / 01 / 2015$ \\
Accepted on: $04 / 02 / 2015$ \\
Available online: $27 / 02 / 2015$ \\
\hline Key words: \\
Sintoc bark oils, eugenol, \\
analgesic, anti-inflammatory.
\end{tabular}

\begin{abstract}
Sintoc bark (Cinnamomum sintoc $\mathrm{Bl}$ ) belongs to Lauraceae (the laurel family). It has been used empirically for a treatment for swelling caused by insects' bites. In this study, the research examined the analgesic activity and anti-inflammation of essential oil of sintocbark using in vivo methods. The mechanism of anti-inflammation was predicted using molecular docking against COX-2. Essential oil of sintoc bark was collected by distilling through steam distillation, and then analyzed by GC-MS. Analgesic and anti-inflammatory activity was examined by in vivo, which were conducted by writhing and carrageenan-induced methods, respectively. The findings showed that the tested sintoc bark oils contained 36 components of essential oil with eugenol $(38.38 \%)$ as a major compound. In the in vivo experiments, sintoc bark oils with doses $0.005 \mathrm{~mL}, 0.010 \mathrm{~mL}$, and $0.020 \mathrm{~mL} / 20 \mathrm{~g}$ body weight significantly $(\mathrm{p}<0.05)$ reduced the number of writhing of mice when compared to negative control group. All of doses of sintoc bark oils gave significantly affect (confidence level $99 \%$ ) compare to negative control. Sintoc oil with dose $0.2 \mathrm{ml} / 200 \mathrm{~g}$ had the strongest inhibition compare to positive control (indometasin $10 \mathrm{mg} / \mathrm{kg}$ body weight). The molecular docking results indicated that the compounds of aryl propanoid were generally potential to inhibit COX-2.
\end{abstract}

\section{INTRODUCTION}

Inflammation is a mechanism of the body's defense caused by the tissue response to such detrimental effects-both local or inside the body (Nathan, 2002). The effects can be devastating to physics, chemistry, bacteria, parasites and so forth. Physical damage can be caused by high temperature, light and radiation, including foreign objects inside the organ, or any causes that prompt devastating effects. Strong acids, strong bases and toxins immerse in chemical causes. Pathogenic bacteria of Streptococcus, Staphylococcus and Pneumococcus genus, for instance, are also devastating (Khansariet al., 2009). Inflammatory reaction can be observed from clinical symptoms around affected tissue, such as increase in heat (calor), reddish

* Corresponding Author

Muchtaridi Muchtaridi, Pharmaceutical Analysis and Medicinal Chemistry, Faculty of Pharmacy, Universitas Padjadjaran, Bandung, Indonesia. Email: muchtaridi@unpad.ac.id spots indication (rubor), pains (dolor) and swelling (tumor) along with itching. It is followed by the changes in structural tissues that lead to loss of functions. Those damaged cells release inflammatory mediators, such as, histamine, bradykinin, serotonin, prostaglandins, and leukotrienes. The process of inflammation causes a change in blood flow, an increased permeability of blood vessels, or a damage of tissue through an activation and migration of leukocytes by synthesizing reactive oxygen derivatives and synthesis of inflammatory mediators locally. Oxidative stress caused by free radicals potentially have physiological or biochemical effects in metabolic disorders that lead to the death of cells. It suggests that antioxidants play a role to heal an inflammation. A synthesis of inflammatory mediator is inducted by phospholipase, cyclooxygenase (COX) and lipooksigenase (LOX) enzymes (Gilroy et al., 1999). Arachidonic acid in cell membranes will be esterified into phospholipids, while the others are in the form of complex lipids. In prostaglandins biosynthesis, arachidonic acid will be released from lipid storage cells byacyl hydrolase. 
Two strands of arachidonic acid metabolisms are COX flow which produces prostaglandins and thromboxane, and LOX-5 flow which produces leukotrienes (Vendramini-Costa and Carvalho, 2012). Research on anti-inflammation has also conducted in some other Cinnamomum genus like essential oil of C. insularimontanum fruit that has an anti-inflammatory activity in vitro by inhibiting NF-kappa B as well as effectively reducing edema inducted in mice's ear at dose of $0.3 \mathrm{mg}$ for each ear that reduces edema of $83 \%$ (Wiart, 2006).It proves that there is a potentiality of a plant belonging to Cinnamomum genus to be an anti-inflammatory drug. In Indonesia, the only simplicia immersed in Cinnamomum genus that has been listed in Indonesian Herbal Pharmacopoeia is C. burmani Ness ex Bl., while the others have not been examined much, including sintoc bark (C. sintoc B1.) (Health, 2008).

Sintoc (C. sintoc Bl.) is a plant that grows in Indonesia, Malaysia and Thailand with a woody stem extending involved in Lauraceae tribe. Empirically, sintoc is utilized as outer or inner medicines. It is used to treat worms in the belly, amoebic dysentery and swelling (inflammation). Instead of Indonesia, research on chemical contents of sintoc bark has also been conducted in other countries. Jantan et al. examines chemical contents in sintoc bark form Malayan peninsula by means of gas chromatography with a mass spectroscopy (Jantan et al., 2005). They concluded that the chemical contents in it are safrole $23.4 \%, 13.5 \%$ murolen, along with such adequate amounts of eugenol, linalool, germakren, kadinen, terpinol, and the other terpenes.

Research on the activity of essential oil of sintoc bark from Malaysia shows that the essential oil has an in vitro antiinflammatory activity by antagonizing LOX and platelet activating factor (PAF), while in vivo, it inhibits edema in mice's ear induced by tetradekanoilphorbol acetate (TPA) (Jantan et al., 2005b). According to the mention above, the laboratory examination was conducted due to investigating an antiinflammatory activity of essential oil of sintoc bark through an inhibition of COX-2 enzyme. The research was aimed at finding out the mechanism of essential oil in sintoc bark towards an inhibition of COX-2 enzyme.

\section{MATERIAL AND METHOD}

A laboratory experimental research is conducted through two steps; the first step is distilling essential oil of sintoc bark by applying steam distillation method and analyzing the essential oil with GC-MS, then determining the level of essential oil and optical rotation. The second step is examining analgesic and antiinflammatory activity in vivo using writhing and carrageenaninduced methods, respectively.

\section{Tools}

To analyze the essential oil with Gas ChromatographyMass Spectrometry method and examine the inhibitory activity of $\mathrm{COX}-2$, the tools used are microplat, $\mathrm{CO}_{2}$ incubator (Sanyo),
Laminar Air Flow (LAF) (Jeio Tech), High Speed Refrigerated Centrifuge (Union $32 \mathrm{R}$ ), otoklaf (Memert), cells counter (Improved Double Nubauer depth 0,1 mm) microscope (Niken Eclipse 80) and microplate reader (Benchmark).

\section{Plant Material}

Sintoc barks from AM were collected in November 2009 from Yogyakarta district. Specimens were identified by the Herbarium Laboratory, Department of Biology, Faculty of Mathematics and Natural Sciences, Universitas Padjadjaran and voucher specimens was submitted to the Herbarium Biology Department, Faculty of Mathematics and Natural Sciences, Universitas Padjadjaran. Sintoc barks (1 kg) was dried in air for 14 days at room temperature to produce dry samples, each weighing $0.5 \mathrm{~kg}$ of barks prepared for the distillation.

\section{Animals}

The animals in this experiment were used Swiss albino mice weighing between $15-35 \mathrm{~g}$ for evaluation of analgesic activity. These animals were divided into five different groups each containing six animals. Male rats of Wistar strains weighing 200-250 grams each was used for antiinflammatory experiment. Food was obtained 12 hours prior to drug administration till completion of experiment. All experimental procedures for animal use have been approved by the Ethical Committee of Experimental Animals.

\section{Physicochemical Analysis \\ Determining Density}

Determining essential oil density was carried out by utilizing a pycnometer. A certain amount of essential oil was incorporated into the pycnometer with its weight and volume measured, and then weighed it using an analytical balance. Essential oil density could be observed from the reduction of essential oil weight in pycnometer with the empty pycnometer weight.

\section{Determining Optical Rotation}

Essential oil of sintoc barks ( $1 \mathrm{~mL})$ was dissolved into nhexane until it reached $10 \mathrm{~mL}$, and homogenized afterwards. The mixture was put into $100 \mathrm{~mm}$ polarimeter tube and then put under the checker tool between the polarizer and the analyzer. The analyzer was slowly rotated and viewed through a telescope until it obtained the same light intensity of illumination. The rotation direction was determined whether it was dextro $(+)$ if clockwise, or levo (-) if counter clockwise. The analyzer was rotated in accordance with the rotation direction until the position between two fields can be viewed clearly and sharply. Degrees on a position of middle-light and middle-dark were written down.

\section{Determining Refractive Index}

The determination of refractive index was performed by applying an abbe refractometer. The tool was installed sufficiently, thus the sodium light illuminated. Prior using it, a prism on 
refractometer was cleansed by acetone as the oil to be tested was dripped into the prism by turning a screw on the prism, hence the prism could be slightly opened, and then the screw was shut completely. The slide was driven back and forth until it formed such a gas/ribbon colour vividly and divided into two parts: bright and dark.

\section{Determining Viscosity}

Viscosity determination of essential oil of sintoc bark was carried out by using an Otswald viscometer. The essential oil was poured into the viscometer through the end point of the tube with a large diameter. Previously, the viscometer was placed on stative in the bottom of the tube and soakedit in water to keep the temperature stable as $25{ }^{\circ} \mathrm{C}$. Furthermore, the essential oil was sucked by a pipette ball through the end point of the tube with a small diameter, until it passed the upper limit. The time required for the essential oil to flow down from the upper limit was measured afterwards. At this point, viscosity was calculated by the formula below:

$$
\eta 0=\left(\mathrm{d}_{0} \times \mathrm{t}_{0}\right) /(\mathrm{dw} \times \mathrm{tw}) \times \eta \mathrm{w}
$$

$\eta \mathrm{o}=$ oil viscosity

$\eta \mathrm{w}=$ water viscosity

$\mathrm{do}=$ oil density

$\mathrm{do}=$ water density

to $=$ the time limit for oil to flow down from the upper limit to the lower limit

ta $=$ the time limit for water to flow down from the upper limit to the lower limit

\section{Determining of Ester Value}

The essential oil was weighed two times to five times, and then dissolved in $5 \mathrm{~mL}$ of neutral ethanol p. Free acid in the oil was neutralized by $\mathrm{KOH}$-ethanol $0,1 \mathrm{~N}$ using an indicator of 1 $\mathrm{mL}$ phenolphthalein. Subsequently, added $25 \mathrm{~mL}$ of $\mathrm{KOH}$-ethanol $0,4 \mathrm{~N}$ and refluxed it on a water bath for 1 hour 30 minutes and cooled eventually. The excess of $\mathrm{KOH}$-ethanol was retritrated by $\mathrm{HCl} 0,5 \mathrm{~N}$ using $1 \mathrm{~mL}$ of phenolphthalein indicator. Afterwards, conducted a blank titration by making a sample containing $5 \mathrm{~mL}$ of neutral ethanol p, and then added $25 \mathrm{~mL}$ N. In subsequent, both $\mathrm{KOH}$-ethanol 0,4 $\mathrm{N}$ are differentiated, after that the solution was refluxed for about 1 hour 30 minutes, then cooled and titrated by $\mathrm{HCl} \mathrm{0,5} \mathrm{titration} \mathrm{which} \mathrm{was} \mathrm{equal} \mathrm{as} \mathrm{the} \mathrm{bases} \mathrm{needed} \mathrm{to} \mathrm{soap} \mathrm{the}$ esters. Ester value were calculated by the following formula:

$\mathrm{a}=$ volume $(\mathrm{HCl})$ of required

$$
\frac{(b-a) \times \mathrm{N} \mathrm{HCl} \times 56,1}{W} \times 100 \%
$$

$\mathrm{b}=$ volume $(\mathrm{HCl})$ of required forms

$\mathrm{w}=$ weight $(\mathrm{g})$ of the substances utilized

\section{Determining of Solubility in Ethanol}

Ethanol solution was made from various concentrations $(50 \%, 60 \%, 65 \%, 70 \%, 75 \%, 80 \%, 90 \%$, dan 95\%). Essential oil $(0.1 \mathrm{~mL})$ was inserted into a lid, and then slowly added a small amount of ethanol into it, started from the lowest concentrations. The ethanol volume added was written down when the clear solution had been obtained before the volume reached $1 \mathrm{~mL}$. If the volume reached $1 \mathrm{~mL}$, but the mixture was not clear yet, the other higher concentrations could be used.

\section{Isolation of essential oil}

Dry samples (1 kg barks) on steam-distillation in Monaco Lembang, West Java, for 3 hours to isolate the essential oil fraction. Oil stored at $-20^{\circ} \mathrm{C}$ after the addition of sodium sulfate.

\section{Analytical Condition}

Essential oils were analyzed on QP5050A GC/MS(Shimadzu) equipped with a fused silica capillary DB-5ms $30 \mathrm{~mm}$ x $0.25 \mathrm{~nm}, 0.25 \mu \mathrm{m}$, carrier gas helium $95.3 \mathrm{kPa}$, flow rate $1.7 \mathrm{ml} /$ minutes. Temperature has been setup with the program as follows: $60{ }^{\circ} \mathrm{C}$ for 5 minutes and then $250^{\circ} \mathrm{C}$ to $10^{\circ} \mathrm{C} / \mathrm{min}$, ending with 5 minutes at $300^{\circ} \mathrm{C}$. Port Injector and detector temperature was $250^{\circ} \mathrm{C}$ and $280^{\circ} \mathrm{C}$, respectively. The sample is injected by split and split ratio 1:20. MS operating conditions were: interface temperature $240{ }^{\circ} \mathrm{C}$; electron impact ionization at $70 \mathrm{eV}$ by scanning the mass range $(\mathrm{m} / \mathrm{z})$ of $40-350$ daltons with a sampling rate of 1.0 scans / s. Identification of compounds was done by searching on a computer using a digital library of mass spectral data by a Class-5000 software and by comparison of retention indices and mass spectra library authentic(Adams, 1995; Ausloos et al., 1999; Babushok et al., 2007; Strehmel et al., 2008), relative to the C8-C20 and C21-C40 n-alkane series (Sigma) (Mijin et al., 1999) in temperature-programmed run.

\section{Analgesic Activity Test}

Acetic acid induced writhing method was employed for evaluation of analgesic activity(Mishra, Ghosh, Kumar, \& Panda, 2011). For inducing, acetic acid $1 \%$ (v/v) solution was used, while solution of aspirin (dose-65 mg/kg/10ml) was prepared in normal saline water. The solution of sintoc oil was achieved with mixing sintoc oil into PGA $10 \%$.

The animals were divided in each group five as mention below: Negative Control: PGA $10 \%$

Positive Control: Acetosal $65 \mathrm{mg} / \mathrm{kg} / 10 \mathrm{ml}$

Sintoc bark oils I: Doses $0.005 \mathrm{~mL} / 20 \mathrm{~g}$

Sintoc bark oilsII: Doses $0.010 \mathrm{~mL} / 20 \mathrm{~g}$

Sintoc bark oilsIII : Dosis $0,020 \mathrm{~mL} / 20 \mathrm{~g}$

The sintoc bark oils and control drugs were administered orally. The writhing was induced by intraperitonial (i.p) injection of $1 \%$ acetic acid in volume of $0.1 \mathrm{ml} / 20$ gbody weight after 60 minutes. The writhing episodes were observed every $5 \mathrm{~min}$ in a 60 minutes; stretching movements consisting of arching of the back, elongation of body and extension of hind limbs were counted. The data was analyzed by ANOVA statistics. The percent protection at each dose-level was achieved by calculating using formula as follows (Subarnas \& Wagner, 2000):

$\%$ protection $=\%$ mean writing of acetosal $/ \%$ mean writing of sintoc bark oils $\times 100$ 


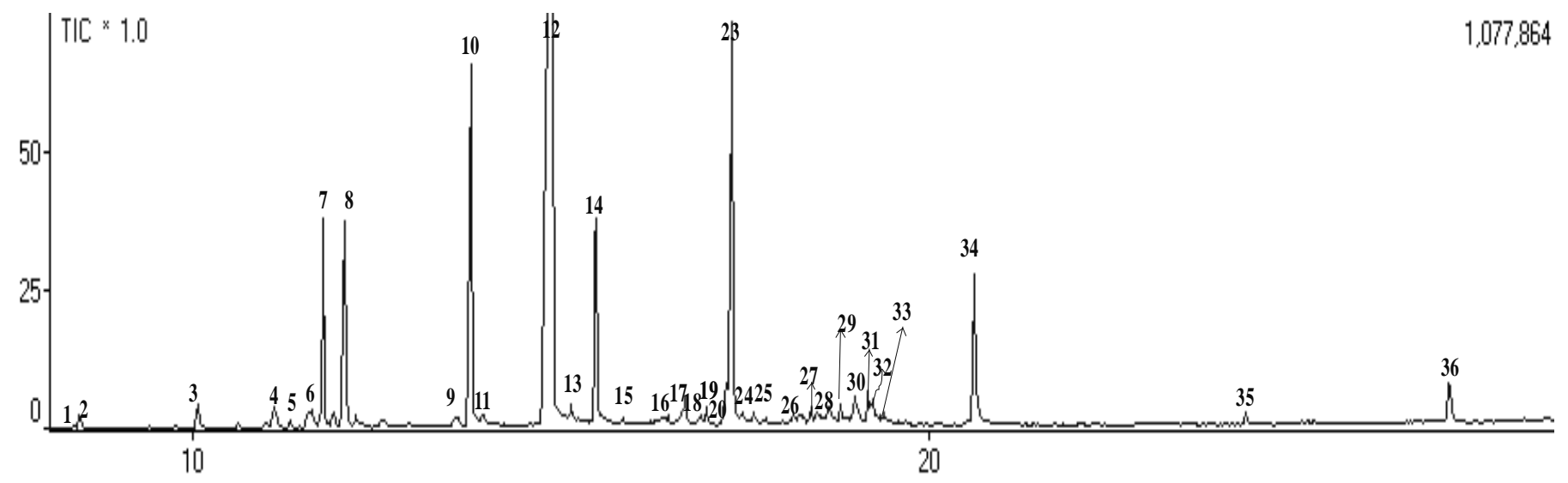

Fig. 1: Total ion chromatogram of sintoc bark essential oils.

Table 1: Psychical characteristics, chemical characteristics and the level of essential oil of sintoc bark.

\begin{tabular}{ll}
\hline \multicolumn{2}{c}{ Evaluation } \\
$\begin{aligned} \text { Level of Essential Oils } \\
\text { Organoleptic }\end{aligned}$ \\
& - Coulor \\
& - Smell \\
& - Taste
\end{tabular}

Density

Refraction index

Viscosity

EsterValue

Solubility in ethanol

\section{Results}

$1.1 \%$

\author{
Green yellowish \\ Strong \\ Spicy \\ 0.964 \\ $1,4986 \mu \mathrm{D}\left(20^{\circ} \mathrm{C}\right)$
}

$3,66 \mathrm{cp}$ (at room temperature)

17.96

10 drops in etanol 50\%

Table 2: The composition of essential oil in sintoc bark.

\begin{tabular}{|c|c|c|c|c|c|}
\hline No. Peak & Retention Time & LRI $\exp ^{b}$ & LRI Ref ${ }^{\text {a }}$ & Name Compounds & \% Area Under Curve \\
\hline & 8.392 & 1028 & 1031 & L-Limonene & 0.08 \\
\hline & 8.473 & 1033 & 1039 & 1,8-sineol & 0.27 \\
\hline & 10.083 & 1095 & 1098 & L-linalool & 0.47 \\
\hline & 11.129 & 1140 & 1146 & Isopulegol & 0.72 \\
\hline & 11.583 & 1146 & 1143 & Camphor & 0.41 \\
\hline & 11.628 & 1162 & 1165 & Borneol & 0.48 \\
\hline & 11.781 & 1174 & 1177 & 4-terpineol & 4.26 \\
\hline & 12.077 & 1191 & 1189 & $\alpha$-terpineol & 4.40 \\
\hline & 13.613 & 1275 & 1285 & bornyl acetate & 0.31 \\
\hline & 13.785 & 1287 & 1285 & Safrole & 10.17 \\
\hline & 13.958 & 1291 & 1290 & Tymol & 0.25 \\
\hline & 14.894 & 1358 & 1356 & Eugennol & 38.38 \\
\hline & 15.152 & 1372 & 1376 & $\alpha$-Copaene & 0.47 \\
\hline & 15.485 & 1400 & 1401 & Methyleugenol & 4.14 \\
\hline & 15.855 & 1412 & 1408 & Trans-caryophylene & 0.06 \\
\hline & 16.403 & 1420 & 1418 & $\beta$ - caryophylene & 0.06 \\
\hline & 16.463 & 1428 & 1439 & Aromadendrene & 0.17 \\
\hline & 16.643 & 1444 & 1477 & $\gamma$-murolene & 0.17 \\
\hline & 16.698 & 1450 & 1483 & $\alpha$-curcumene & 0.50 \\
\hline & 16.903 & 1486 & 1499 & $\alpha$-murolene & 0.16 \\
\hline & 17.217 & 1508 & 1503 & gernacrene & 0.22 \\
\hline & 17.254 & 1518 & 1524 & $\delta$-cadinene & 0.78 \\
\hline & 17.343 & 1520 & 1520 & myristicin & 13.54 \\
\hline & 17.634 & 1540 & 1542 & $\alpha$-calocorene & 0.28 \\
\hline & 17.803 & 1575 & 1576 & Spatulenol & 0.07 \\
\hline & 18.161 & 1582 & 1581 & Caryophylene oxide & 0.20 \\
\hline & 18.243 & 1587 & 1583 & Globulol & 0.20 \\
\hline & 18.292 & 1591 & 1590 & Viridiphlorol & 0.14 \\
\hline & 18.648 & 1620 & - & Isomyrisiticin & 1.14 \\
\hline & 19.005 & 1638 & 1640 & $\delta$-cadinol & 1.63 \\
\hline & 19.182 & 1648 & 1653 & alfa-cadinol & 0.98 \\
\hline & 19.256 & 1665 & 1691 & Junipher camphor & 0.69 \\
\hline & 19.342 & 1700 & - & Eugenic acid & 0.24 \\
\hline & 20.622 & 1760 & 1762 & Benzyl benzoate & 4.66 \\
\hline & 24.316 & 1857 & - & Derivative eugenol & 0.28 \\
\hline & 27.073 & 2176 & - & Hexadecanoic acid & 1.00 \\
\hline
\end{tabular}

a LRI reference in Adams (1995) with DB5 column

b LRI experiment with DB5-MS column 


\section{Anti-inflammatory activity}

Anti-inflammatory activity was evaluated using a carrageenan-induced paw edema test methods(Subarnas \& Wagner, 2000). The animals were divided into control and test groups. Each group contained of 5 rats. The rats were injected of $0.1 \mathrm{ml}$ of $1 \%$ carrageenan into the subplantar tissue of the right hindpaw of each ratsas $30 \mathrm{~min}$ after the i. p. administration of the test compound or control vehicle. The paw edema was achieved before and 1 to 5 hours after the carrageenan administration using a plethysmometer. Doses of sintoc bark oils were administered at $0.05 ; 0.10$ and $0.20 \mathrm{~mL} / 200 \mathrm{~g}$ body weight of rat.

The inhibition percentage of edema was achieved by calculating using equation as follows:

$\%$ Inhibition $=\frac{\text { edema of indomethacin }-\% \text { edema of sintoc bark oils }}{\% \text { edema of indomethacin }} \times 100$

\section{Statistical analysis}

Data were analyzed using an ANOVA, and the significance of difference was calculated according to the Newman Keuls.

\section{RESULTS}

\section{The Contents of Essential oil Ki Lemo}

The result of testing physical and chemical characteristics of essential oil of sintoc bark $(C$. sintoc Bl.) is shown in Table 1. According to the table, it can be seen that the value of essential oil of sintoc bark density is $0,964 \mathrm{~g} / \mathrm{cm}^{3}$. It is in the range of essential oil density which is between 0.696$1.18 \mathrm{~g} / \mathrm{cm}^{3}$ (Guenther, 1990).

\section{The Compositions of Essential Oil of Sintoc Bark}

The compositions of essential oil of sintoc bark were shown by Figure 1. On the figure, it can be seen that the greatest peak is at no. 12 (eugenol), while none of monoterpena compounds stand out in the compositions of essential oil of sintoc bark. Eugenol was major compound (38.38 \%), respectively followed by myristicin (13.54 \%), safrole $(10.17 \%)$, metileuegunol (4.14\%). The complete data can be seen in Table 2 . The contents of 4-terpinol (4,2 \%) and $\alpha$-terpineol $(4.4 \%)$ from sintoc bark are not as great as the contents of aryl propanoid compound derivatives.

\section{Analgesic Activity of Essential Oil of Sintok}

Examining the analgesic activity of essential oil of sintoc barkhad been done by $0.7 \%$ PGA-induced writhing method, and its further effectiveness was compared to aspirin $65 \mathrm{mg} / \mathrm{kg}$. Essential oils with doses $0.005 \mathrm{~mL}, 0.010 \mathrm{~mL}$, and $0.020 \mathrm{~mL} / 20 \mathrm{~g}$ of sintoc bark significantly $(\mathrm{p}<0.05)$ reduced the number of writhing of mice when compared to negative control group. The result of examination is shown in Table 3. The writhing was observed for 60 minutes. In this study, PGA $10 \%$ was used as negative control and solution of asetosal as positive control. As shown Table 3, Doses of sintoc bark oils were $0.005 \mathrm{~mL}, 0,010$
$\mathrm{mL}$, dan 0,020 mL/20g body weight. Based on Table 3 and Fig. 2, all doses of sintoc bark oils of administered decreased the writhing numbers of mice.

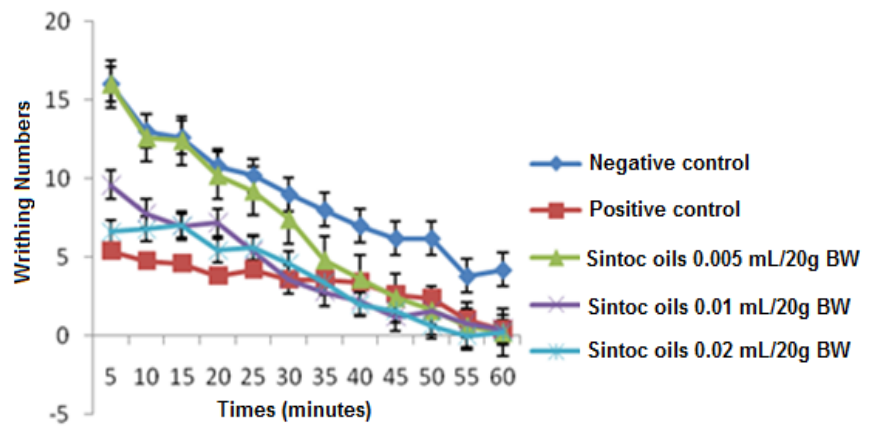

Fig. 2: Effect of sintoc bark oils onthe acetic acid - induced writhing response in mice.

Dose of $0.005 \mathrm{~mL} / 20 \mathrm{~g}$ body weight provided significantly affect $(\mathrm{p}<0.01)$ compare than negative control since 35 minutes, while dose of $0.005 \mathrm{ml} / 20 \mathrm{~g}$ body weight contributed significantly affect each minute to ten and to five. The results showed a dose-dependent increase in the decreasing of writhing of mice as compared to the positive control (acetosal $65 \mathrm{mg} / \mathrm{kg}$ body weight). It was very interesting to note that sintoc oil was more selective for the analgesic activity as demonstrated by the high writhing inhibition percentage of mice in the control. The percentage of pain protection and effectiveness therapy could be calculated based on the data of mention above by comparing the effects of acetosal. The results were showed in Table 4 and Fig. 3 . Table 4 and Fig. 3 showed that a dose-dependent increase in the increasing of protection capacity of pain by induced acetic acid 0.7 $\%$ as compared to the control. In addition, a dose-dependent of sintoc bark oils increased more increase of therapy effectiveness compare than acetosal $65 \mathrm{mg} / \mathrm{kg}$ body weight. Statistics analysis results showed that there were significantly different belong treatment at $\mathrm{p}<0.01$. It was mean that all of the doses of sintoc bark oils gave significantly effect compare than negative control (PGA $10 \%$ ).

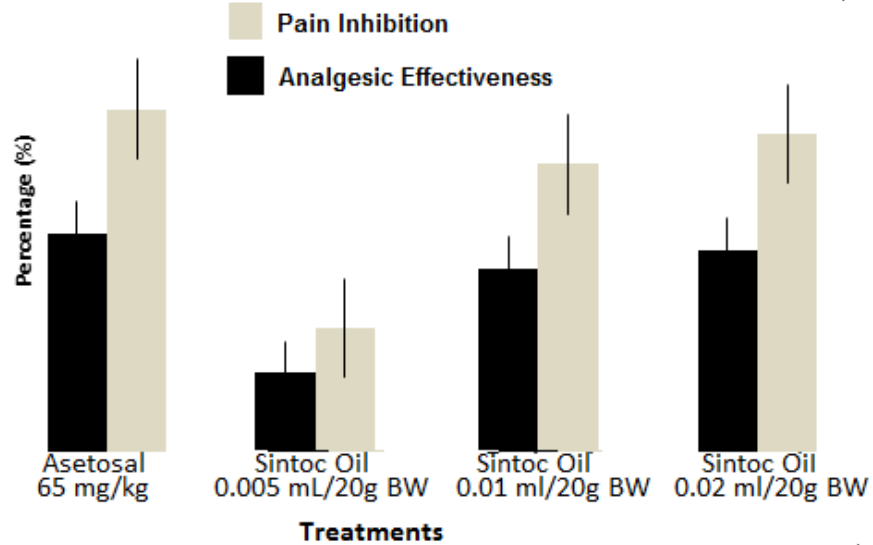

Fig. 3: Graph of pain protection percentage and effectiveness of essential oils sintoc bark 
Table 3: Effect of sintoc bark oils on the acetic acid-induced writhing response in mice over $60 \mathrm{~min}$.

\begin{tabular}{|c|c|c|c|c|c|c|c|c|c|c|c|c|c|}
\hline \multirow{2}{*}{ Treatment Groups } & \multicolumn{12}{|c|}{ Average numbers of Writhing every 5 minutes in 60 minutes } & \multirow{2}{*}{-Total } \\
\hline & 5 & 10 & 15 & 20 & 25 & 30 & 35 & 40 & 45 & 50 & 55 & 60 & \\
\hline Control (-) & 16 & 13,4 & 12,6 & 10,8 & 10,2 & 9 & 8 & 7 & 6,2 & 5 & 3,8 & 3,5 & 105 \\
\hline Acetosal $65 \mathrm{mg} / \mathrm{kg}$ & 5,4 & 4,8 & 4,6 & 3,8 & 4,2 & 3,6 & 3 & 2,9 & 2,4 & 2,1 & 1 & 0,4 & $38,2 *$ \\
\hline Sintoc bark oils I & 16 & 12,6 & 12,4 & 10,2 & 9,2 & 7,4 & $4,8^{*}$ & 3,6 & 2,4 & 1,6 & 0,6 & 0,2 & $81 *$ \\
\hline Sintoc bark oils II & 9,6 & $7,8 *$ & $7 *$ & $6,5^{*}$ & $5,4^{*}$ & $3,6^{*}$ & $2,8 *$ & $2,2 *$ & $1,2 *$ & $1,6^{*}$ & $0,8^{*}$ & $0,4^{*}$ & $48,9 *$ \\
\hline Sintoc bark oils III & $7 *$ & $6,8 *$ & $6,5^{*}$ & $5,4^{*}$ & $5,0 *$ & $4,6^{*}$ & $3,4 *$ & $2 *$ & $1,6^{*}$ & $0,6^{*}$ & $0 *$ & $0,2^{*}$ & $43,1 *$ \\
\hline
\end{tabular}

Tabel 4: Percentage of pain protection and effectiveness of essential oils sintoc barks.

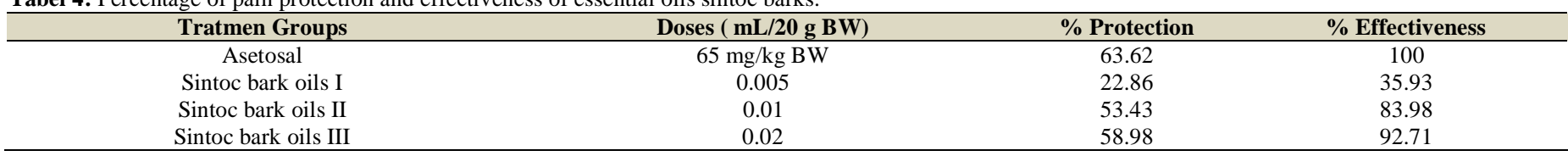

Table 5: Percentage of means average in evaluation of anti-inflammatory activity of sintoc bark oils.

\begin{tabular}{|c|c|c|c|c|c|c|}
\hline \multirow{2}{*}{ Treatment Groups } & \multirow{2}{*}{$\operatorname{Doses}(\mathrm{mL} / 200 \mathrm{~g})$} & \multicolumn{5}{|c|}{ Percentage of means average of paw edema of rats (\%) (in hours) } \\
\hline & & 1 & 2 & 3 & 4 & 5 \\
\hline Control (-) & PGA & 47.69 & 101.6 & 141.53 & 188.00 & 221.01 \\
\hline Indometasin & $10 \mathrm{mg} / \mathrm{kg}$ & 13.44 & 44.76 & 78.82 & 109.59 & 85.31 \\
\hline Sintoc bark oils I & 0.05 & 25.66 & 91.96 & 130.95 & 110.02 & 96.73 \\
\hline Sintoc bark oils II & 0.10 & 21.34 & 45.58 & 96.43 & 71.30 & 57.10 \\
\hline Sintoc bark oils III & 0.20 & 13.01 & 39.83 & 86.31 & 55.83 & 35.06 \\
\hline
\end{tabular}

\section{Anti-inflammatory Effect of Sintoc bark oils}

Sintoc bark oils were evaluated the anti-inflammation activity using Winter methods by inducing paw edema of male rats. As shown in Table 5 and Fig.4, all doses of sintoc bark oils weight inhibited plantar edema in the mice (induced by $1 \%$ of carrageenan) significantly compare to negative control. In Fig.4, a dose-dependent of sintoc bark oils increased in decreasing paw edema of rats. The inhibition of edema percentage was clearly shown in Fig.4.

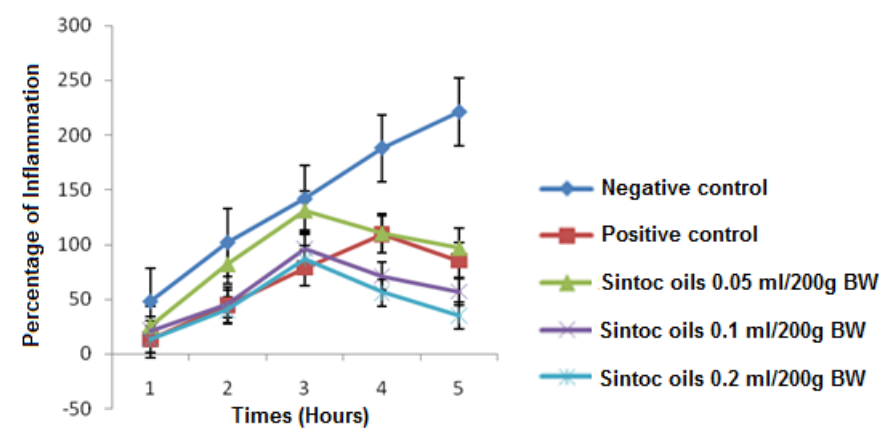

Fig. 4: Percentage of means of inflammation of paw edema of rats each treatments.

The significant inhibition caused by a dose of $0.2 \mathrm{~mL} / \mathrm{kg}$ body weight occurred from 1 to 5 hours after the administration of carrageenan compare then positive control (indometasin $10 \mathrm{mg} / \mathrm{kg}$ body weight). However, the doses of 0.05 dan $0.1 \mathrm{~mL} / 200 \mathrm{~g}$ body weight gave percentage inhibition less than positive control. The percentage of inhibition of inflammation could be measured from Table 4 and the data was shown in Table 6 and Fig. 5. Percentage inhibition of inflammation illustrated the capability of compounds tested to inhibit the formation of edema. This value could be determined though the edema scores of the compounds tested. The groups that obtained small edema percentage had high capability to inhibit of the edema. Tabel 6 showed that inhibition edema percentage of sintoc bark oils increased in line with the increasing of doses. It indicated that a dose-dependent increased more increasing the activity in edema percentage inhibition of sintoc bark oils that induced by carrageenan. In the Table 6 , sintoc bark oils clearly appeared that sintoc oil with dose $0.2 \mathrm{ml} / 200 \mathrm{~g}$ had the strongest inhibition compare to positive control (indometasin 10 $\mathrm{mg} / \mathrm{kg}$ body weight). All of doses of sintoc bark oils gave significantly affect (confidence level $99 \%$ ) compare to negative control. However, the doses of 0.05 and $0.1 \mathrm{ml} / 200 \mathrm{~g}$ body weight had less inhibition compare to positive control.

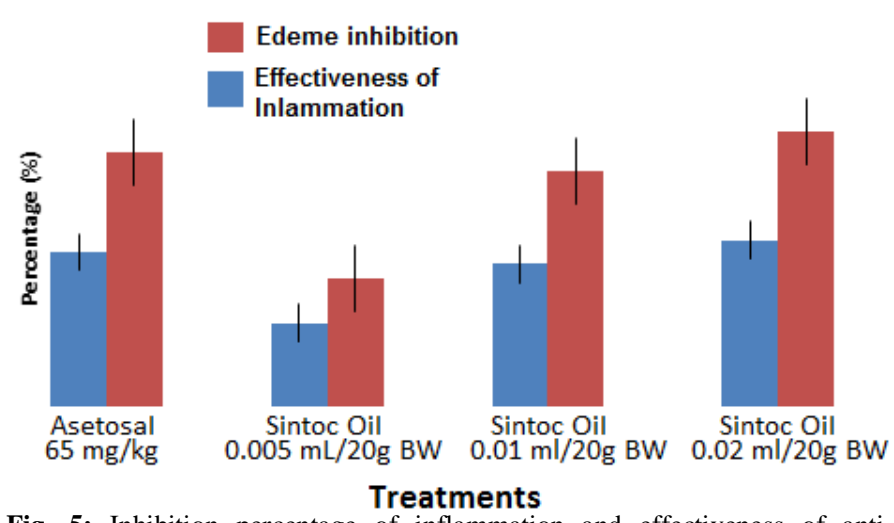

Fig. 5: Inhibition percentage of inflammation and effectiveness of antiinflammation of sintoc bark oils.

Table 6: Percentage of Inhibition of Edema and Effectiveness of Antiinflammatory of Sintoc bark oils.

\begin{tabular}{cccc}
\hline Treatment Groups & $\begin{array}{c}\text { Doses } \\
(\mathbf{m L / 2 0 0 g})\end{array}$ & $\begin{array}{c}\text { Inflammation } \\
\text { Inhibition } \\
(\mathbf{\%})\end{array}$ & $\begin{array}{c}\text { Effectiveness of } \\
\text { Anti-inflammatory } \\
(\mathbf{\%})\end{array}$ \\
\hline Indometasin & $10 \mathrm{mg} / \mathrm{kg}$ & 60.40 & 100 \\
Sintoc bark oils I & 0.05 & 32.67 & 50.09 \\
Sintoc bark oils II & 0.10 & 55.83 & 92.43 \\
Sintoc bark oils III & 0.20 & 65.35 & 108.18 \\
\hline
\end{tabular}




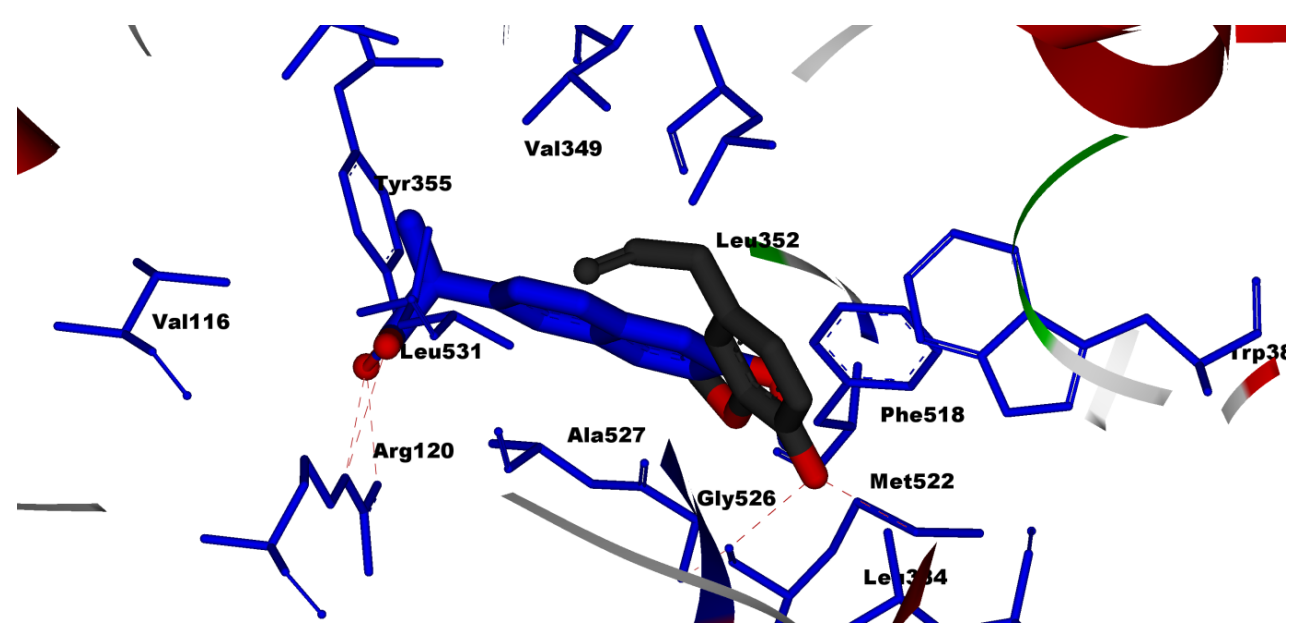

Fig. 6: Binding interaction of eugenol (black carbon) that imposed into naproxen (control ligand-blue carbon) against binding site of COX-2.

\section{The Prediction of Essential Compounds Relational Interaction towards COX-2 through Molecular Docking}

According to previous research (Chericoni, et al., 2010; Thakur and Pitre, 2009), here we predicted that the mechanism of eugenol might acts against cyclooxygenase- 2 target.

According to Table 3, only alcohol compounds derivatives that had the ability to compete as the inhibitors of COX-2, while none of essential compounds was commonly able to compete with the control compounds of naproxen. In the table, 4terpinol compound had the lowest binding energy, which means that it is the most competitive compound to be an inhibitor of COX-2, yet eugenol compound had a better interaction visually. Phenol part of eugenol (black carbon) forms hydrogen bound with Met522 and Gly 526 from COX-2, as well as phenol part of naproxen (blue carbon). Nevertheless, eugenol does not form electrostatic interaction in between carboxyl and ammonium ions as well as carboxyl groups of naproxen with ammonium ions of Arg 120. The description is shown in Figure 6.

Table 7: Molecular docking results of some components of sintoc bark oils

\begin{tabular}{llll}
\hline No & Name Compounds & $\begin{array}{c}\text { Free Energy } \\
\text { Binding } \\
\text { (kcal/mol) }\end{array}$ & $\begin{array}{c}\text { Ki } \\
\text { (Inhibition Constant) }\end{array}$ \\
\hline $\mathbf{1}$ & Naproksen (kontrol) & -7.55 & $40 \mathrm{nM}$ \\
$\mathbf{2}$ & eugenol & -5.69 & $68.02 \mu \mathrm{M}$ \\
$\mathbf{3}$ & L-linalool & -4.90 & $220 \mu \mathrm{M}$ \\
$\mathbf{4}$ & Isopulegol & -4.89 & $246 \mu \mathrm{M}$ \\
$\mathbf{5}$ & 4-terpineol & -6.36 & $56.12 \mu \mathrm{M}$ \\
$\mathbf{6}$ & a-terpineol & -5.20 & $93.5 \mu \mathrm{M}$ \\
$\mathbf{7}$ & Safrol & -4.64 & $323 \mu \mathrm{M}$ \\
$\mathbf{8}$ & 1,8-sineol & -5.21 & $98.1 \mu \mathrm{M}$ \\
$\mathbf{9}$ & metileugenol & -5.60 & $70 \mu \mathrm{M}$ \\
$\mathbf{1 0}$ & miristisin & -5.58 & $80.74 \mu \mathrm{M}$ \\
$\mathbf{1 1}$ & isomirisitisin & -4.88 & $234 \mu \mathrm{M}$ \\
\hline
\end{tabular}

\section{DISCUSSION}

The result of analyzing essential oil in Gas Chromatography-Spectroscopy period (GC-MS)shows that the largest component of essential oil in sintoc bark is eugenol $(38,38$ $\%)$, followed by other compounds which have smaller percentages, such as 4-terpineol, 1-terpineol, camphor, methyl trans-isogenol, dan alpha-pinene. Here we also showed that our results is significantly different from previous studies from other countries (Malaysia) (Jantan et al., 2005). Jantan et al. (2005) declared that linalool (23.4\%) and $\gamma \gamma$-muurolene $(13.5 \%)$ were the major components of the bark oil and surprisingly eugenol has been not detected in sintoc bark oils. It might be caused that the geographic and seasonal factors may be important in determining the chemical composition (Muchtaridi et al., 2014).

In the examination of pharmacology activity, it is proved that essential oil of sintoc bark has analgesic activity on stretching method. Analgesic activity is indicated by the decrease in the times of mice stretching induced by acetic acid $0.7 \%$. The decrease in the amount of stretching indicates that the essential oil can protect a pain caused by acetic acid.

The effect of inhibition edema was studied along a 60min test, as shown in Figure 5. In addition, sintoc bark oils also provided anti-inflammatory activity, which is related to the previous evidence that essential oils that contained eugenol inhibits edema in rats (Chericoniet al., 1994; Thakur andPitre, 2009). However, the anti-inflammatory activity seen weak, as it was observed only at a higher dose $(0.2 \mathrm{~mL} / 200 \mathrm{~g}$ body weight $)$. These results suggest that this oils might have effective antinflammation activity.

Sharma et al. (1994) propose that respective doses of 33 $\mathrm{mg} / \mathrm{kg}$ eugenol and ginger oil given on the right knee and right foot of mice for 26 days induced by Mycobacteiun tuberculosis significantly decrease the inflammation. The research conducted by Cherironi et al. (2005) has also proved that essential oil and eugenol bark of $C$. zeylanicum Bl. in vitro inhibit an antiinflammation induced by peroxynitrite and lipid peroxidation, which reduce 3-nitrotyrosin formation with $\mathrm{IC}_{50}$ 18,4 and 46,7 $\mu \mathrm{g} / \mathrm{mL}$ respectively.

In addition, Thakcur and Pitre (2009) prove that eugenol form essential oil of basil (Ocimum sanctum L.), as much as 100 $\mathrm{mg} / \mathrm{kg}$ of body weight, is able to inhibit an inflammation on the mice's foot induced by keragenan as much as $33 \%$. It is also supported by research that proposes the increase of COX-2 expression induced by tioasetamida (TA) can be inhibited by 
eugenol (Yogalakshmi, Viswanathan, \& Anuradha, 2010). Furthermore, Magalhaes et al. (2010) show that eugenol has an anti-inflammatory activity in vivo by inhibiting LPS in an injured lung, improving lung function. In line with the notion, bioactive compound of essential oil that is responsible for inhibiting COX-2 activity is apparently précised through molecular docking. It could be concluded that the compounds of aryl propanoid was generally potential to inhibit COX-2 operation. In previous study, molecular docking results has shown that isoeugenol can effectivelyinhibit cyclooxygenase and lipoxygenase enzymatic action. Docking results of isoeugenol against COX-2 (PDB ID: 4COX) shows that the molecule docked into the active site with similar orientation with indomethacin (Zarlaha etal., 2014).

\section{CONCLUSION}

The essential oils of sintoc bark contained $1.1 \%$ essential oils with eugenol $(38.3 \%)$ as major component. The essential oils of sintoc bark had analgesic an anti-anflammatory activities. In molecular prediction, eugeunol had better prediction, while none of essential compounds was commonly able to compete with the control compounds of naproxen

\section{REFERENCES}

Adams, R. P.. 1995.Identification of Essential Oil Components by Gas Chromatography/Mass Spectroscopy Illinois: Allured Publishing Corporation.

Ausloos, P., Clifton, C. L., Lias, S. G., Mikaya, A. I., Stein, S. E., Tchekhovskoi, D. V., Sparkman, O. D., Zaikin, V., \& Zhu, D. The critical evaluation of a comprehensive mass spectral library. J Am Soc Mass Spectrom, 1999;. 10(4), 287-299.

Babushok, V. I., Linstrom, P. J., Reed, J. J., Zenkevich, I. G., Brown, R. L., Mallard, W. G., \& Stein, S. E. Development of a database of gas chromatographic retention properties of organic compounds. J Chromatogr A,2007;1157(1-2), 414-421.

Chericoni, S., Prieto, J. M., Iacopini, P., Cioni, P., \& Morelli, I. In vitro activity of the essential oil of Cinnamomum zeylanicum and eugenol in peroxynitrite-induced oxidative processes. J Agric Food Chem,2005;53(12), 4762-4765.

Gilroy, D. W., Colville-Nash, P. R., Willis, D., Chivers, J., Paul-Clark, M. J., \& Willoughby, D. A. Inducible cyclooxygenase may have anti-inflammatory properties. Nat Med, 1999;5(6), 698-701.

Guenther, E. 1990. The Essential Oils -: History-Origin in Plants - Production - Analysis. New York:Read Books.

Health, D. o. M. o. Indonesia Herbal Pharmacopea. In M. o. Health (Ed.), vol. 1 (pp. 164-165, 168-171) . 2008, Jakarta: Department of Health.

Jantan, I., Rafi, I. A., \& Jalil, J. Platelet-activating factor (PAF) receptor-binding antagonist activity of Malaysian medicinal plants. Phytomed,. 2005;12(1-2), 88-92.

Jantan, I.B., Yalvema, M.F., Ayop, N., \& Ahmad, A.S. Constituents of the essential oils of Cinnamomum sintoc Blume from a mountain forest of Peninsular Malaysia. Flav. Frag.J, 2005b; 20(6),601604.
Khansari, N., Shakiba, Y., \& Mahmoudi, M. Chronic inflammation and oxidative stress as a major cause of age-related diseases and cancer. Recent Pat Inflamm Allergy Drug Discov,2009;3(1), 73-80.

Magalhaes, C. B., Riva, D. R., DePaula, L. J., Brando-Lima, A., Koatz, V. L., Leal-Cardoso, J. H., Zin, W. A., \& Faffe, D. S. In vivo antiinflammatory action of eugenol on lipopolysaccharide-induced lung injury. J Appl Physiol,2000; 108(4), 845-851.

Mijin, D. Z., Petrovic, S. D., \& Antonovic, D. G. Gas Chromatography Retention Indices of 2-Phenyl- 2 Alkylacetonitriles on Packed Coloumns. The Sci. J. Fact. Univ,1999;2(1), 1-8.

Mishra, D., Ghosh, G., Kumar, P. S., \& Panda, P. K. An Experimental Study of Analgesic Activity Of Selective COX-2 Inhibitor with Conventional NSAIDs. Asian J. Pharm. Clin. Res,2011;4(1), 78-81.

Muchtaridi, M., Musfiroh, I., Subarnas, A., Rambia, I., Suganda, H., \& Nasrudin, M. E. Chemical Composition and Locomotors Activity of Essential Oils from the Rhizome, Stem, and Leaf of Alpinia malaccencis (Burm F.) of Indonesian Spices. J. Appl. Pharma. Sci, 2014;4(1), 52-56.

Nathan, C. Points of control in inflammation. Nature, 2002; 420(6917), 846-852.

Sharma, J. N., Srivastava, K. C., \& Gan, E. K. Suppressive effects of eugenol and ginger oil on arthritic rats. Pharmacology,1994; 49(5), 314-318.

Strehmel, N., Hummel, J., Erban, A., Strassburg, K., \& Kopka, J. Retention index thresholds for compound matching in GC-MS metabolite profiling. J Chromatogr B Analyt Technol Biomed Life Sci,2005;871(2), 182-190.

Subarnas, A., \& Wagner, H. Analgesic and anti-inflammatory activity of the proanthocyanidin shellegueain A from Polypodium feei METT. Phytomed,. 2000;7(5), 401-405.

Thakur, K., \& Pitre, K. S. Anti-Inflammatory Activity of Extracted Eugenol from Ocimum sanctum L. Leaves. Rasayan J. Chem,2009;2(2), 472-474

Vendramini-Costa, D. B., \& Carvalho, J. E. Molecular link mechanisms between inflammation and cancer. Curr Pharm Des, 2012; 18(26), 3831-3852.

Wiart, C. Ethnopharmacology of Medicinal Plants Asia and The Pacific. 2006, Totowa, New Jersey: Humana Press.

Yogalakshmi, B., Viswanathan, P., \& Anuradha, C. Investigation of antioxidant, anti-inflammatory and DNA-protective properties of eugenol in thioacetamide-induced liver injury in rats. Toxicology,2010,268(3), 204-212.

Zarlaha, A., Kourkoumelis, N., Stanojkovic, T. P., \& KovalaDemertzi, D. (2014). Cytotoxic Activity of Essential Oil And Extracts of Ocimum basilicum Against Human Carcinoma Cells. Molecular Docking Study of Isoeugenol As A Potent COX And LOX Inhibitor. Dig. J. Nanomat. Biostruc, 2014; 9(3), 907 - 917

\section{How to cite this article:}

Sri Adi Sumiwi, Anas Subarnas, Supriyatna Supriyatna, Marline Abdasah, Muchtaridi Muchtaridi. Analysis of Chemical Composition and its Analgesic and Anti-Inflammatory Acitvity of Essential oil of Sintoc Bark (Cinnamomum sintocbl.) Using in vivo Methods. J App Pharm Sci, 2015; 5 (02): 058-065. 